\title{
DIREITOS HUMANOS À RENDA DIGNA E AO DESENVOLVIMENTO SUSTENTÁVEL
}

\section{Enio Waldir da Silva}

Doutor em Sociologia, mestre em Sociologia, bacharel e licenciado em Filosofia. Professor das áreas de Ciências Humanas e Ciências Aplicadas da Unijuí. Pesquisador do Mestrado em Direitos Humanos. enioteixeira63@ gmail.com

\section{Resumo}

Argumentamos que a agenda de debate de qualquer projeto de desenvolvimento sustentável deve incluir a questão social e a questão cultural como elementos fundamentais da perspectiva econômica. Isto quer dizer que as experiências de trabalho e renda de grupos populares, cooperativados ou não, formais ou informais, devem fazer parte dos esforços que tentam promover o justo e sustentável desenvolvimento, uma vez que estas experiências contêm novidades para garantir vivências, convivências e alternativas mais que econômicas. Usando a metodologia da pesquisa-ação participante recolhemos inúmeras visões de indivíduos que se sentem excluídos dos debates sobre desenvolvimento e justificam a grande porcentagem de pessoas que vivem de trabalhos e rendas que poderiam fazer parte do horizonte de planejamento social. As experiências destas atividades mostram que podem ser alternativas inclusivas e objetos de políticas públicas de desenvolvimento social, cultural, político, ecológico, além do econômico.

\section{Palavras-chave:}

Dignidade. Sustentabilidade. Trabalho. Cooperativismo.

\section{HUMAN RIGHT TO DIGNIFIED INCOME AND SUSTAINABLE DEVELOPMENT}

\begin{abstract}
We argue that the agenda of discussion of any sustainable development project must include the social question and the cultural issue as fundamental elements of economic perspective. This means that the experiences of work and income of popular groups, co-ops, or no, formal or informal, should be part of the efforts to try to promote the fair and sustainable development, since these experiences contain news for guarantee experiencies, retreas and more economic alternatives. Using the methodology of action research participant collected


numerous visions of individuals who feel excluded from discussions about development and the large percentage of people of jobs and incomes that could be part of the planning horizon social. These experiments show that activity can be inclusive alternatives and public policies for social development, cultural, political, ecological, beyond the economic.

\section{Keywords:}

Dignity. Sustainability. Work. Cooperatives.

Recebido em: 28/9/2017

Aceito em: 4/10/2017

\section{Sumário:}

1 Introdução. 2 A Solidariedade e Dignidade para Viver e Conviver Cultivadas na Economia Solidária. 3 Direitos Humanos e Desenvolvimento Sustentável. 4 Conclusões. 5 Referências. 


\section{INTRODUÇÃO}

Este texto é fruto das atividades junto a Economia Solidária que realizamos na Região Noroeste do Estado do RS. Discute o trabalho e renda como um direito humano dos grupos populares e apresenta as dimensôes complexas que estes enfrentam para participar dos debates, programas e projetos voltados para o desenvolvimento das regióes.

A dinâmica metodológica que usamos advém da pesquisa-ação participante que fazemos com diversos grupos organizados que estão sendo orientados pelos princípios de economia solidária. São pequenas cooperativas e associaçôes de variados tipos que atuam para garantir a sobrevivência e lutam como movimentos sociais que procuram mudar a política de inclusão social. Ao mesmo tempo, por suas redes de influências, criam perspectivas de sociedade alternativas e justas que se contrapóem à pura lógica do capitalismo.

Fundamentamo-nos na compreensão teórica das Ciências Sociais críticas que entendem que é tempo de agregar esforços das lutas emancipatórias das comunidades em vulnerabilidade social ou de comunidades populares que buscam, coletivamente, trabalho, renda e vida digna sustentável. A experiência com trabalho coletivo já é evidente nos grupos da economia solidária. O que se almeja agora é evoluir para um novo cooperativismo alternativo que consolide novas racionalidades, que considere as vivências coletivas pacíficas, o trabalho como fonte de ética e vida individual e coletiva, além contribuir para o respeito à natureza da vida humana e ao meio ambiente.

Em um primeiro momento procuramos entender as dinâmicas socializantes da economia solidária, o sentido de solidariedade, renda digna e direitos humanos. $\mathrm{Na}$ sequência verificamos os potenciais civilizacionais dos processos cooperativos, especialmente as dimensôes educativas para uma nova gramática social que fundamente políticas de desenvolvimento social, político, cultural e econômico sustentável. 


\section{A SOLIDARIEDADE E DIGNIDADE PARA VIVER E CONVIVER CULTIVADAS NA ECONOMIA SOLIDÁRIA}

A economia solidária é compreendida por nós em três dimensōes: a) como uma prática econômica por onde parcela da população busca garantir renda e trabalho de excluídos; b) como um movimento que luta por inclusão social e defesa do associativismo, cooperativismo popular e desenvolvimento sustentável e c) como uma proposta de vida social alternativa ao sistema capitalista que seja permeada pela solidariedade, dignidade humana, sustentabilidade e justiça igualitária.

Como tal, possui diversos discursos ligados aos atores que a integram e apoiam. Mapeamos parte destes discursos e estudamos até que ponto a prática da economia solidária poderia ser fonte para concretizaçáo dos direitos humanos e de inovaçóes nas formas de sociabilidade. Verificamos então que a luta pela concretização dos direitos humanos encontra ressonância nas práticas desses grupos organizados pela economia solidária, especialmente quando essas associaçóes e cooperativas conseguem garantir trabalho e renda mais constantes para todos os seus membros. A consolidação da autonomia desses grupos expressa também poderes para fortalecimento da democracia participativa, dos saberes emergentes, decentes, urgentes e prudentes, pois são frutos de atores sociais munidos de liberdades substantivas concretas (trabalho e renda). As experiências da economia solidária traduzem os inúmeros potenciais em que ela pode ser usada para assegurar vida digna a muitos indivíduos.

Milhares de redes de economia solidária que vão se organizando pelo mundo afora, tornam-se poderosos atratores, capazes de irradiar desenvolvimento sustentável nos territórios que alcançam, na medida em que integrem estrategicamente seus fluxos de meios econômicos (bens tangíveis e intangíveis) e seus fluxos de valores econômicos (MANCE, 2008, p. 192). Esta expressão indica as imaginaçôes que estáo sendo criadas em torno das práticas de economia solidária como alternativas sistêmicas ao capitalismo e noticiam sobre a amplitude da economia solidária como contraposto sistêmico. Numa missão de promover o bem-viver das pessoas e a paz entre os povos pela prática de uma consciência que já está nas pessoas, a economia solidária teria o germe de uma revolução pacífica. 
É uma consciência que se gesta na razão prática do trabalho solidário autogestionário, pela distribuição equitativa das rendas e riquezas produzidas, pela mudança educativa e cultural dos grupos envolvidos e nas redes de conexóes que traçam. Ou seja, não há indivíduo que seja contra um justo trabalho, uma justa renda e uma vida de paz e bem-viver. Esta força é interna e está na lógica humana que exige integração de um Eu a um Outro, para juntos viverem. A lógica do sistema da vida humana é visualizada na lógica de uma proposta sistêmica de vida social, que não ameaça a lógica sistêmica do planeta. É aqui que devemos pensar a solidariedade da vida humana com a solidariedade do sistema planetário, perceptível como participação de pessoas que consomem ar, água, terra e energia e seus frutos. Estes orientados pela economia solidária compreendem que náo se pode destruir a fonte que sustenta a vida na terra pela própria força do entendimento de que eles mesmos são exemplos de exclusão e desrespeito que a lógica capitalista proporciona (SILVA, 2010).

Então, com os princípios da economia solidária se aprende que a solidariedade envolve relaçóes como a natureza e o meio ambiente, relaçóes sociais, ideias e o bom uso do conhecimento. Como não somos todos iguais, procuramos fazer açôes junto com o outro de modo a não desprezá-lo e nem sermos tratados degradadamente por ele, ou, ainda, por sermos seres humanos iguais, a solidariedade significa aquele aspecto de nossa existência que entende que precisa do outro e que o outro precisa de mim. Se nascemos com a força solidária em nossa natureza (dependemos da mãe, do pai...), ao nos inserirmos na sociedade a solidariedade vai enfrentando muitos obstáculos para naturalmente se manifestar e se tornar social e, como tal, sofre os vícios de toda a socialização por dependência. A solidariedade faz parte de uma cultura de reconhecimento e pertencimento a um mundo que precisa de convivência e complementaridade, sustentabilidade e respeitabilidade (ZOLL, 2007).

Quanto maior a cultura de solidariedade, maior a possibilidade de alcançarmos uma vida moral coletiva, de modo a entender a dor e a humilhação do Outro, propondo a inclusão do "diferente" no nosso grupo social, aumentando os nossos acordos intersubjetivos e a referência a um Nós. Ações solidárias não são linguagens apenas de contingência que exigem apenas gentilezas, mas um permanente diálogo que desconstrói os ambientes de humilhação dos outros, favorecen- 
do, assim, uma cultura de convivência dos diferentes. Entender a solidariedade é ver os agrupamentos de sujeitos livres que compartilham compromissos e açóes coletivas, unidos mediante o sentimento de pertencimento coletivo, do compartilhamento dos interesses, da cidadania, de reconhecimento de sujeitos de direito. Neste sentido a solidariedade instaura a liberdade. Certamente, em uma sociedade esfacelada como a nossa, a solidariedade é também força e objetivo de lutas individuais e coletivas. Significa que a solidariedade não brota de sujeitos munidos de misantropias e atravessados por necessidades substanciais. É necessário uma via de mão dupla diante da responsabilidade em gerar renda digna: empenho individual e apoio das condiçóes oferecidas pela sociedade, isto é, as necessidades primárias e genuínas devem estar instauradas na concretude estrutural da vida social para que possa exercer a responsabilidade pessoal da dignidade.

A dignidade tem uma concretude de onde ela brota: a qualidade de vida, ou seja, quando o sujeito náo passa fome, quando consegue manter sua saúde ou recuperá-la, quando possui moradia, quando tem acesso à educação escolar, quando consegue viver sua afetividade, quando consegue falar e ser ouvido e, especialmente, quando consegue trabalhar e auferir renda digna.

Há lugares em que grupos produzem riquezas para poderem melhor aproveitar sua vida, torná-la prazerosa, fazer das trocas uma forma de relação social. Alguns descobriram que a vida podia ser de outro modo longe da competição e da concorrência e criaram alternativas que davam sentido ao direito de viver segundo a natureza social dos sujeitos. Se sofremos quando o outro sofre e lutamos para diminuir o sofrimento dele, nos dedicamos ao Outro como nos dedicamos a um Nós. Isso quer dizer que somos solidários e não competidores.

Trata-se de refletir em escala planetária, adotando a "identidade terrena" de que fala Edgar Morin (2008). Pensar a longo prazo, levar em conta as geraçóes que ainda não nasceram, mas que sofrerão as consequências de nossas escolhas atuais. Inserir-se em uma visão ecológica e privilegiar o desenvolvimento duradouro, não separando a espécie humana dos outros componentes da natureza. Muitos buscam no outro os elementos de igualdade, como a amizade, a compreensão, a solidariedade e, quando encontram as diferenças, respeitam-nas e buscam formas de saber tratá-las, conviver com elas. 
Em muitos lugares percebem-se sabedorias subjacentes, não colonizadas e nem colonizadoras. Assim, se os laços vivos da liberdade persistem contra a lógica perversa do aprisionamento do lucro imediato, não há por que, como destaca Habermas (2002), nos desesperarmos com o poder, a razão e o Estado. Estamos vivos, pensantes e capazes de linguagem, na universidade, na rua, na associação, na comunidade, entáo tudo pode ser criado. Para Boaventura de Sousa Santos (2009), estas experiências de vidas emancipadas espalhadas por aí necessitam serem unidas em uma nova alternativa de vida, em uma nova epistemologia e na utopia da igualdade que continua viva. Essas práticas solidárias estáo ao alcance de qualquer pessoa, pois falam a gramática do social, uma vez que os homens não agem somente porque estão presos a uma situação tornada insuportável, mas também porque estão ligados a certas visóes do possível.

E a renda é um substrato fundamental que concretiza e motiva as vidas. Ela garante a sua liberdade substantiva como alimento, trabalho, educação e saúde, e permite que sejam aproveitadas as oportunidades econômicas, a liberdade de escolhas, as facilidades sociais, as transparências e a segurança. Por isso não há "sujeito desespero" e o fundamento da dignidade da humanidade da vida está em qualquer pessoa. Não se trata de imaginar um super-homem capaz de resolver todos os problemas que a afetam, mas de entender os problemas e criar esforços para resolvê-los. As liberdades substantivas de que desfrutamos, contudo, para exercer nossas responsabilidades, são extremamente dependentes de circunstâncias políticas, culturais, sociais, econômicas e ambientais.

A economia solidária congrega estas dimensóes. Esta surgiu das antigas formas de trabalho familiar; transformou-se em uma alternativa de renda dos desempregados; se fortalece com as associaçôes de catadores nas grandes cidades; se expande com o fortalecimento da agricultura familiar e do artesanato; se consolida com a criação de estudos de sua realidade, com o apoio das universidades incubadoras e com as políticas públicas; se globaliza como sendo uma forma de fazer empreendimentos produtores de renda constante diante das oscilaçóes do mercado.

Hoje está buscando maior reconhecimento, melhor organizaçáo e mais tecnologias para instituir seus fins de trabalho solidário e autonomia. Responde por quase $10 \%$ do PIB brasileiro. Isso apenas das atividades formalizadas, pois o conjunto de atividades informais que garantem trabalho e renda para milhóes de 
famílias é infinitamente maior. Suas atividades estấo 35\% organizadas em forma de cooperativas e 32\% são associaçôes (dados de 2013). Existem 11 leis estaduais sobre economia solidária e está presente, formalmente, em mais de 3 mil municípios. A economia solidária luta por apoio de políticas públicas de diferentes Ministérios: Ministério do Trabalho e Emprego (MTE), com a Secretaria Nacional da Economia Solidária (Senaes) fazendo esforços em manter um setor que garantisse uma estrutura mais permanente de capacidade de fazer frente a várias demandas, mas seus esforços não se consolidaram. Os Ministérios - da Agricultura, Desenvolvimento Social, Saúde, Justiça, Ciência e Tecnologia - poderiam criar uma estratégia para incluir estes grupos da economia solidária, posto que se dizem promotores do desenvolvimento nacional.

A economia solidária, porém, avança de forma heterogênea devido ao enfrentamento do contexto de novos ramos econômicos e da reviravolta da onda neoliberal. É um caminho que a nova Europa vem adotando para proteger seus trabalhadores das oscilaçóes econômicas. Criaram a Academia Europeia de Economia Solidária. A própria OIT recomenda que a economia solidária, com suas prerrogativas de autogestão e cooperação, seja a alternativa para mudar o mundo a favor dos trabalhadores em geral.

\section{DIREITOS HUMANOS E DESENVOLVIMENTO SUSTENTÁVEL}

O pressuposto de que existe uma natureza humana universal que pode ser conhecida racionalmente nos leva a pensar que ela pode ser inserida em uma realidade organizada que a contemple. Não se trata de impor esta organização, mas de participar dela e assumi-la como uma das formas de contemplar nossa diversidade. Provavelmente se tivéssemos acesso àquilo que nos torna dignos teríamos mais força para enfrentar as vulnerabilidades da violência e da estupidez. Minha qualidade de vida baseada na saúde física, intelectual, mental e espiritual produziria menos estranhamento.

Por isso o sonho do movimento dos direitos humanos concretizados é o sonho da sociedade ideal pensada por muitos lutadores sociais. Trata-se de criar uma cultura do nós e não remeter o outro para fora da humanidade. Assim, em todos 
os espaços é possível ser criada esta cultura. O excluído do sistema pode nunca ter ouvido falar desta oportunidade. Pelo trabalho, tem a possibilidade de orientar suas compreensốes para outra vida possível. O trabalho é um direito universal, no entanto estas atividades não devem se assemelhar a trabalhos forçados, cruéis ou degradantes.

Aí está um dos papéis dos direitos humanos: garantir as condições de uma comunicaçáo franca, honesta e autônoma por onde as opinióes e a vontade podem ser entendidas e refinadas a ponto de se institucionalizarem para serem vividas. Embora estejam formalmente escritos, os direitos sociais e humanos não estão sendo efetivados em sua plenitude.

A economia solidária, por sua forma organizativa e prospectiva, é um grande antídoto da violência, uma forma ampla de inclusão social pelo trabalho e renda e se encaixa perfeitamente na estratégia de promoção dos direitos humanos, da justiça e do desenvolvimento. Seu aspecto mais destacado é o educativo. Os relatos de atores atuantes com esta população mostram a forma possível:

A idéia de que a associação do trabalho com a educaçáo são os pilares para a emancipação humana, pois essas duas concepçôes partem do princípio de que os saberes e significados são construídos pelos próprios envolvidos, e não de um saber e conhecimento já pronto e formulado que, muitas vezes, não é significativo para o grupo (SILVA, 2010).

Todos reconhecem que o trabalho tem um papel muito importante em vários sentidos, tanto no sentido de proporcionar uma ocupação, como também representa uma oportunidade de ganhos e de qualificaçáo profissional. O trabalho associado e cooperado contribui para abrir perspectivas de vida e de autoestima. O trabalho é, inquestionavelmente, uma atividade fundamental, sobretudo no sentido de criar oportunidades para que os trabalhadores possam experimentar perspectivas novas de vida.

A Economia Solidária poderia melhor cumprir suas perspectivas se estiver acoplada a um programa sistêmico do Estado e de direitos humanos. Se não possuir um amplo programa de políticas públicas de socialização, os efeitos da economia solidária no atual sistema serão muito residuais. É a lógica perversa de exclusão da 
sociedade capitalista que torna as pequenas experiências em uma síntese da cultura de desrespeito à dignidade da vida. Por outro lado, resta claro que a apresentação de meios alternativos de vida amplia as potencialidades solidárias das pessoas.

No debate em fóruns, congressos, conferências e nas formaçóes de grupos há o esforço para ampliação das culturas e conhecimentos sobre cooperativismo popular e os princípios da Economia Solidária (ES), do associativismo, da tecnologia social, dos direitos humanos e da educação popular. Estas compreensôes são fundamentais para apoiadores dos atores do cooperativismo popular, pois suas açôes não podem se tornar mais um obstáculo aos potenciais que possuem para se organizar, trabalhar e viver coletivamente. Agora é preciso dar sentido à sociedade democrática que coloca a questão de sua transformação, sem, necessariamente, tomar o poder, uma vez que se trata de diluir este empoderamento entre cidadãos atores e agências, ou seja, tornar o poder compartilhado. Além do cumprimento de normas e leis inclusivas, mostra-se as visualizaçóes de vivências livres e responsáveis que um processo cooperativado requer. As mentes precisam estar ativas e motivadas a participar coletivamente das decisóes sobre os interesses comuns, participar da efetivação do que foi decidido e participar da avaliação de resultados que possam ser replicados na coletividade.

As cooperativas populares são as melhores alternativas que se apresentam para os trabalhadores que precisam garantir renda mais constante, respeito e trabalho digno reconhecido. Algumas inciativas para criar uma cooperativa são feitas, mas quase sempre esbarram na falta de apoio mais direto e significativo dos poderes públicos, nas legislaçôes e na falta da cultura de cooperação dos atores.

Não se trata de burocratização de procedimentos, mas de propiciar condições para melhor desenvolver as atividades e gerar trabalho e renda de forma coletiva e solidária, em que se dá a palavra aos participantes para gerar a responsabilidade da escuta, como um convite à motivação racional para entendimentos das proposições coletivas. Se a cooperativa deve nascer de seus criadores, os trabalhadores, este processo demanda parcerias e políticas públicas. Não é, portanto, um projeto simples, somente dos atores, pois responde aos interesses das coletividades desafiadas a respeitar o meio ambiente, a cuidar de seus espaços sociais, a manter a cidade limpa, a ter comida ecologicamente produzida, a fazer a reciclagem de resíduos e 
a respeitar as atividades que náo advêm de emprego meramente empresarial. $\mathrm{O}$ cooperativismo e a economia solidária respondem às necessidades do conteúdo da sociedade democrática: trabalho e renda para todos.

Por isso a democracia é aqui entendida como começo, meio e fim dos processos associativos e cooperativos. Inicia-se no planejamento participativo, desde o momento de diagnóstico, passando pelo estabelecimento de diretrizes, objetivos e metas, execução e avaliação, sempre construindo a cultura do diálogo, da conquista coletiva de autonomia, o compromisso político e ético com a constituição de uma sociedade mais justa.

O desenvolvimento prevê a cooperação entendida como a existência de interesses e objetivos comuns, a união dos esforços e capacidades, a propriedade coletiva de bens, a partilha dos resultados e a responsabilidade solidária. Envolve diversos tipos de organizaçáo coletiva, como empresas autogestionárias ou recuperadas e assumida por trabalhadores; associaçóes comunitárias de produção; redes de produção, comercializaçáo e consumo; grupos informais produtivos de segmentos específicos, como de mulheres, jovens, etc.; clubes de trocas, entre outros. Na maioria dos casos essas organizaçóes coletivas agregam um conjunto grande de atividades individuais e familiares.

Para compreender o cooperativismo em sua versão popular, e a sua efetivação na atualidade, é importante considerar as formas de atuação cooperativista. A prática cooperativa, em geral, e a popular por excelência, impóem açóes que se orientam por princípios que podem ser identificados nas dimensóes sociais, políticas, econômicas, culturais e ambientais.

Seja como terceira via para o desenvolvimento econômico, seja como um instrumento que reforça os princípios liberais e atenua as cíclicas crises do modelo concorrencial ou seja como instrumento de contraposição à ordem liberal, o cooperativismo é uma alternativa para mitigar, combater e superar os efeitos negativos derivados do modelo de produçáo capitalista. No cooperativismo popular há um abrigo na promoção e na articulação de meios, formas e técnicas para vencer a pobreza e a exclusáo social. É um tipo de cooperativismo que se aproxima e se articula com os movimentos de luta pelo exercício fundamental da cidadania que ancora o desenvolvimento sustentável. 
O desenvolvimento é a efetivação universal do conjunto dos direitos humanos, desde os direitos políticos e cívicos, passando pelos direitos econômicos, sociais e culturais e o direito a um meio ambiente saudável. Não se trata de ver nisso uma visão de pós- desenvolvimento que critica as anteriores compreensóes, mas de incluir nele as experiências bem-sucedidas e as experiências novas, includentes e não colonizantes que equilibrem sociedade e natureza num só sistema, que não se aprisionem aos limites políticos das naçóes industrializadas que apenas falam da poluição, da perda de biodiversidade, das alteraçôes climáticas, do esgotamento dos recursos naturais, da destruição da camada de ozônio, etc.

Além destes problemas há as relaçóes entre as pessoas: a fragmentação dos sujeitos, a indignação, o desespero, a ansiedade, a violência, os crimes e a falta de reconhecimento do outro como igual e diferente. Estes problemas estão além da imagem catastrófica ambientalista de algumas mídias. Trata-se da ameaça da prosperidade de atender às necessidades genuínas das populaçóes que este mercado consumista está a promover. Precisamos de uma cultura que respeita a natureza, que não seja voraz no consumo e que não produza descontroladamente, mas também de mentes que não sejam esquizofrênicas, estúpidas e violentas, que riem da sua própria destruição.

Não se pode pensar em desenvolvimento em uma nação na qual a maioria não tem trabalho e renda, não tem moradia, não tem terras, não tem acesso à saúde. Não basta que estes grupos tenham consciência disso, o importante é criar iniciativas para efetivar e experienciar alternativas. Podemos observar que pequenas cooperativas e associaçóes, formadas como pequenas empresas tornam-se exemplos de companheirismo e ajuda mútua entre os participantes e no meio em que vivem. As organizaçôes cooperativas passam a significar importantes espaços de educação, de aprendizagem e de construção do poder, condiçôes necessárias para o enfrentamento das condiçôes adversas. O poder será construído quando os trabalhadores tiverem conquistado a inteligência coletiva e quando o conhecimento socializado seja retrabalhado pelo coletivo (SILVA, 2010).

Para Frantz (2006), o sucesso da gestão democrática e autogestão depende das pessoas, de sua capacitação para a organização sob seu comando e controle, e esta capacitaçáo deve ser constante, pois trata-se de um processo pedagógico que não pode ficar à mercê do espontaneísmo ou afloraçáo natural do conhecimento. 
Uma cooperativa não difere muito de uma empresa juridicamente quando trabalha alinhada para alcançar seus fins, mas também não deve ser confundida com qualquer associação filantrópica, caritativa ou beneficente.

A cultura de cooperação exige posturas democráticas, disposição para o diálogo, visão de poderes compartilhados, relaçôes sociais solidárias, reconhecimento das igualdades e das diferenças, responsabilidade de participar como dever e direito de auferir resultados da participação, ética com a natureza, respeito às ordenaçóes criadas pelos próprios sujeitos da cooperação e às leis do Estado de Direito.

Por isso, para se chegar a uma cooperativa real e efetiva é preciso um longo processo educativo que está além dos sistemas escolares que atualmente possuímos, e além das aprendizagens atuais adquiridas na ordem social, nas mídias, na religiāo, no Estado, na economia, na cultura e, principalmente, nos cotidianos das vivências individuais, familiares e grupais.

Este entendimento, porém, deve advir de processos comunicativos em que os atores sociais tornam-se protagonistas dos diálogos que vão em direção ao seu entorno e provocam a motivaçáo dos atores para expressar entendimentos da pragmática vivenciada. Seus atores precisam também estar movidos por essa vontade de entendimento e de ação coletiva para realizaçáo de interesses universais: o tema do diálogo proposto deve ser a vida em solidariedade (HABERMAS, 2002, p. 45).

Como um germe de sociedade democrática, a economia solidária já experienciou uma razão não instrumental e em vários momentos apresentou condiçôes para a produção de consensos parciais, baseados na argumentação. A vida democrática ali vivida criou um dinamismo próprio de uma esfera pública que está além do Estado, que tematiza a agenda política em relação à qual o Estado deve reagir. A luta agora é a tradução dessa linguagem comum para códigos mais sistemáticos, que seria realizada pelo Direito, uma vez que em essência a argumentação central há muito tempo foi anunciada pelos direitos humanos. Todos os homens têm capacidades de linguagem, todos têm interesses e todos imaginam o futuro: a razáo democrática deve cultivar e promover a comunicação entre esses sujeitos a fim de produzir entendimentos universais para orientar as relaçóes sociais e o poder (HABERMAS, 2002). Por enquanto o instrumentalismo do poder está impedindo esta razão democrática de se reforçar e evoluir. 
Por isso a luta por políticas públicas nada mais é de que uma luta contra-hegemônica, ou anti-hegemônica como observa Sousa Santos (2002), mas tendo o local como fonte destes primeiros passos no fortalecimento da sociedade democrática efetiva. As experiências locais podem virar redes de resistência dos ansiosos. Os líderes políticos estavam aprisionados a compromissos com a elite que quer dinheiro fácil, não conseguem criar políticas públicas que façam emergir a economia real, o pleno emprego e as motivaçóes empreendedoras de novos ramos produtivos. $\mathrm{O}$ Estado fica à mercê do mercado, resolvendo suas crises e com isso endividando-se, e não conseguindo firmar um mercado consumidor de fato dos produtos necessário à população.

Boaventura de Sousa Santos (2002) nos mostra que estas alternativas de produção não capitalistas não são apenas econômicas: o seu potencial emancipatório e suas perspectivas de êxito dependem, em boa medida, da integração que consigam entre processos de transformação econômica e processos culturais, sociais e políticos. O êxito das alternativas de produção depende de sua inserção em redes de colaboraçáo e de apoio mútuo, em que as ansiedades individuais voltem-se para as universais, traçando mapas para emergir soluçóes alternativas (uma vez que a diminuição das ansiedades individuais só é possível com a diminuição da ansiedade de todos). A Economia Solidária teria potencial emancipatório e suas perspectivas de êxito dependem, no mais das vezes, da integração que consigam entre processos de transformação econômica e processos culturais, sociais e políticos. Depende também de sua inserção em redes de colaboração e de apoio mútuo.

A dimensão de solidariedade coloca-se aqui com mais ênfase nas interconexôes (redes) dos indivíduos postados em suas atividades de produção e distribuição, pois estas já são fruto de formas alternativas de conhecimentos. Colocá-las em rede solidarizaria o êxito e o fracasso, produzindo novos saberes e novas alternativas solidárias que sejam fortes e críveis o suficiente para se contrapor à força da lógica capitalista (SOUSA SANTOS, 2002, p. 64-74).

Ao julgar o progresso como sinônimo de desenvolvimento Bauman argumenta que em muitos lugares trata-se de fundar o verdadeiro mercado e não de arrumar o mercado capitalista. Ou seja, em um mercado real todos podem ofertar e todos podem demandar e este movimento sustenta a satisfaçáo das necessidades 
genuínas das pessoas. No mercado capitalista está presente a lógica predatória, que explora sem escrúpulos os recursos naturais e humanos guiados por fins apenas comerciais e moralmente devastadores (BAUMAN, 2008).

$\mathrm{Na}$ concepção de desenvolvimento de Amartya Sen, podemos perceber que o autor insiste em mostrar a dificuldade de você imaginar açóes solidárias em indivíduos municiados de sofrimentos individuais. Precisariam, antes, ter sua liberdade substantiva garantida: alimento, renda, educação, saúde, para que sejam aproveitadas as oportunidades econômicas, a liberdade de escolhas, as facilidades sociais, as transparências e a segurança. $O$ caminho entre liberdade e responsabilidade é de mão dupla. Sem a liberdade substantiva e a capacidade para realizar alguma coisa, a pessoa náo pode ser responsável por fazê-la. Ter efetivamente, porém, a liberdade e a capacidade para fazer alguma coisa impóe à pessoa o dever de refletir sobre fazê-la ou não, e isso envolve responsabilidade individual. Nesse sentido, a liberdade é necessária e suficiente para a responsabilidade. Constata-se entáo que é fundamental para o trabalho dos atores a parceria com o Estado, especialmente o Estado Democrático, para que este proporcione o mínimo de liberdade (as substantivas), sustentando na base o agir responsável das pessoas, ampliando a capacidade individual de auferir rendas que possam ser partilhadas coletivamente (SEN, 2000, p. 321-323).

\section{CONCLUSÕES}

As Ciências Humanas já provaram que a solidariedade é uma das características mais comuns dos sentimentos humanos e é um dos elementos universais presentes na lógica da humanidade dos indivíduos e não a competitividade, como vinham defendendo as concepçóes liberais da modernidade.

Quando essa força humana de solidariedade é percebida e desenvolvida vemos brotar a grandeza da igualdade humana. E foi a idealização de um futuro mais promissor que levou muitos atores sociais a provarem que a grandeza da história humana está marcada pelos momentos em que houve açóes coletivas solidárias. Quando a humanidade apenas competiu, se corroeu, entrou em violência, guerras e decadências. 
Por isso, recuperar os princípios que ligam indivíduos a indivíduos, grupos a grupos, sociedades a sociedades é um dos papéis nobres da educação escolar e da formação humana para além da escola. As práticas solidárias existentes não foram ainda acompanhadas pelo conhecimento científico e pelas açóes de aprendizagem. Nesse sentido defendemos que é preciso reconhecer os laços que integram os sujeitos, pois a vida microscópica dos grupos nem sempre segue as divisóes eleitorais ou econômicas. A convivência (e a solidariedade), despida de seu caráter mítico, corresponde a essas associaçóes de indivíduos que suscitam laços, indubitavelmente passageiros e frágeis, em torno das refeiçóes tomadas em comum, da música, da dança, ou, simplesmente, de uma ligação amigável, laços de vizinhança, de bairros - para além dos tradicionais laços familiares, de trabalho, de clubes, universidades e outros.

Ali se cultiva a afetividade, o prazer, a respeitabilidade e a autoridade, que raramente se cristalizam em organizaçóes ou associaçôes ou seitas. Os homens estão ligados a certas visôes do possível e possuem esperanças. As situaçôes que ainda não foram vividas mobilizam mais forças do que os constrangimentos, pois a natureza social do homem leva-o a imaginar sempre um ideal, a ter sempre uma expectativa do outro e a aspirar laços além daquilo que recebeu quando nasceu (DUVIGNAUD, 1986).

A Sociologia está fazendo esforços para a compreensão do conceito de sustentabilidade que seja adequada ao entendimento de que a vida pode ser digna, pode ser justa e solidária, aqui e agora, assim como daqui a um pouco ou amanhá. $\mathrm{Na}$ nossa pesquisa notamos a presença constante do discurso de desenvolvimento social sustentável. Os sujeitos envolvidos nesta dialógica compreensiva, com suas falas e gramáticas próprias, foram dando significados especiais ao conceito. Assim, o desenvolvimento sustentável é entendido em cinco (5) dimensões:

a) Social: A sustentabilidade como o foco no social relaciona-se, em primeira mão, ao entendimento da solidariedade que promove a vida familiar, as conexóes afetivas das pessoas que vivem próximas e ao mesmo tempo é preciso manter e fortalecer os laços sociais, as relaçóes que garantem e protegem as convivências humanas na comunidade, no trabalho, na escola... Trata-se de tornar os sujeitos fortes para terem autonomia e civismo responsável pela organização social pacífica e agregadora dos grupos humanos. A pessoa necessita sentir-se incluída 
e reconhecida na vida social, na sociedade em que vive. Trata-se de construir novas concepçóes de coesão social, no sentido de fortalecimento de redes de confiança, de respeitabilidade das diferenças e das igualdades, de convivência nos cotidianos das famílias, dos grupos, das associações, etc. Ou seja, saber viver juntos iguais e diferentes (TOURAINE, 1998).

b) Cultural: A sustentabilidade no sentido cultural agrega os esforços educativos em se criar uma nova cultura que respeite a diversidade, promova e fortaleça a aprendizagem pertinente, a educação emancipadora nos diversos espaços sociais. Tornar a escola uma verdadeira fotossíntese da boa civilização enraizada na cultura da solidariedade, da igualdade e da liberdade, no sentido de que estes conceitos sejam chaves para combater a lógica capitalista. Ou seja, a dimensão cultural da sustentabilidade deve combater o ópio do consumismo e criar uma nova cultura de sociedade com capacidade de suprir as necessidades edificantes da vida coletiva, como aquelas expressas nos direitos fundamentais e nos direitos humanos. Assim todos os artefatos (mídias) e artes passam a ser o poder simbólico da nova cultura de viver juntos, iguais e diferentes (multiculturalidade).

Esta dimensão está ligada à afirmação da identidade dos indivíduos e à organização de seus aprendizados. É o desafio de conhecer sua historicidade, localidade, perspectivas, experiencialidades, valores, costumes, expressóes artísticas, tecnologias, etc. Trata-se de socializar a cognicidade existente e emergente, criando espaços para diálogos de entendimentos orientadores de decisóes para ações coletivas (HABERMAS, 1995; FRANTZ, 2008).

c) Econômica: A dimensão econômica da sustentabilidade trata de instituir, de fato, o princípio da produção igual, distribuição igual. Ou seja, uma sustentabilidade que inclua todos no trabalho digno e na renda digna. Nem tanto emprego, mas garantia de trabalho. Neste caso, trata-se de combater as formas perversas de produtivismos, comercialismos, consumismos e combate à exploração do trabalho e da vida. Neste conceito insere-se a concepção de tecnologia social, que além de tecnologia adequada para a economia popular também é a forma organizativa de trabalho solidário que facilita e amplia a produção e distribuição. Neste sentido o princípio geral é de que ninguém tem direito de ficar sem trabalhar (trabalho é próprio da lógica humana - bio-lógica), assim como ninguém tem direito de 
se apropriar e explorar o trabalho dos outros. Saber ter bens e desfrutar deles é pensar um sistema econômico que não permite a acumulação de bens para ostentação de uns e miséria de outros.

Há necessidades substanciais e imediatas e necessidades que estão no interior de uma projeçáo de vida alternativa embasada nas experienciaçôes da economia solidária. Trata-se de uma prática cidadã que traz impactos nas experiências de produção e distribuição de renda, tais como: número de postos de trabalhos criados, o valor dos rendimentos proporcionados, o grau de utilizaçáo de insumos, a dinâmica do consumo local e as açóes nas diferentes lógicas das relaçóes mercantis, não mercantis e não monetárias. Ou seja, estimula novos círculos de relações econômicas de autoconsumo, intercâmbios de produtos e serviços náo monetarizados, mecanismos de subsidiariedade para produção e consumo nas relaçôes com os poderes públicos (transferências governamentais, isençóes tributárias ou outras formas de subsídio), utilização coletiva de recursos (equipamentos, propriedades, etc.) e diferentes formas de finanças solidárias, entre outras. A gestão cooperada é um aprendizado imprescindível (FRANTZ, 2008).

d) Política: A sustentabilidade política envolve as propostas de autogestão, cogestão, cooperativismo, cidadania participativa e a diversidade de formas democráticas (a exemplo da Demodiversidade, de Boaventura de Sousa Santos, 2002). Ou seja, garantir espaços de motivação racional para a participação nos processos decisórios, espaços para todos poderem contribuir para a instituiçẫo destas decisões, para a avaliação dos resultados e promoção de novos planejamentos. Significa pôr um fim nas hierarquias rígidas entre quem planeja e quem executa, um fim na cultura patrão x empregado, enraizando a cultura da corresponsabilidade, como o dever e a ordem social igualitária como direito. Entra aqui um novo papel do Estado democrático e efetivação de políticas públicas, mas também a ideia de que embora os sujeitos não sejam totalmente responsáveis pela situação em que vivem eles são responsáveis por sair das más situaçôes em que se encontram. Aqui trata-se de fortalecer a autonomia dos grupos locais no processo de gestão da experiência: fortalecer a participação das pessoas; buscar açôes de políticas públicas; formar redes de ancoragem com parceiros francos; gerenciar as diferenças em hierarquias apenas funcionais e não privilegiadas (SOUSA SANTOS, 2002; SEN, 2000). 
e) Sustentabilidade: No sentido ambiental concentram-se as principais ideias e concepçôes de criar uma ética universal dos indivíduos sobre sua relação com a terra, ar, água e energia. Não é um romantismo ou demagogia das chamadas empresas verdes. Entre tantos conceitos roubados das lutas das classes populares este da sustentabilidade ambiental é o mais complicado. A natureza é bonita e sadia porque ela não é uma coisa externa à vida do homem. É interna. Como posso envenenar e tratar mal, poluir e destruir a terra, a água, o ar e a energia de onde tudo vem para manter a minha vida? Não adianta falar em proteção dos animais, das florestas, das flores, se isto tudo vem da terra... Entâo, trata-se de recuperar para equilibrar o sentido da vida do ser mais importante nesta cadeia ambiental, o homem. Como argumenta Morin (2005), é preciso recuperar sua unidade psicológica, sociológica, biológica e pedagógica para que sua razão humana náo se desvie de seus fins: manter equilibrada a vida saudável da terra, da água, do ar e das diferentes formas de energia.

Esta dimensão avalia a forma de manejo dos recursos ambientais por meio das atividades desenvolvidas: a produção e uso da tecnologia, qualificação da relação entre meio ambiente e processo produtivo; utilizar recursos sem efeito poluidor; energias renováveis e, finalmente, importa avaliar o nível de geração de resíduos pelas atividades, bem como seu modo de tratamento. Não esquecer, portanto, que isso faz parte um sistema maior, que insere o homem com sua lógica humana na natureza com sua lógica (MORIN, 2005).

Estas concepçôes somente enraízam sua validade se elas estiverem presentes na concepçáo de todos os envolvidos com as projeçóes de desenvolvimento, mas principalmente se forem vivenciadas pelas classes populares, os verdadeiros sujeitos das transformaçóes sociais. Estes também precisam enfrentar os obstáculos para se fortalecerem em cooperativas sociais populares, como o de vencer as dimensôes societais opressoras que estão no entorno e nas consciências. Falta imaginar, querer e lutar pelo novo. Tem-se dificuldades para construir capacitaçóes mais constantes, pois trata-se de um processo pedagógico que não pode ficar à mercê do espontaneísmo ou afloraçấo natural do conhecimento. É o cooperativismo que condensa experiências que podem traduzir-se em conhecimentos construídos que dão uma direção possível de ser assumida após entendimentos coletivos dialogados. Não serão os obstáculos jurídicos, filantrópicos, caritativos, beneficentes das atuais experiências 
cooperativas que irão impedir a emergência de um projeto de cooperativa bem construída, não por um grupo isolado de atores que precisam da cooperativa, mas pelos atores em parcerias dialógicas com apoiadores (ITCPS, ONGs, etc.) e com o poder público democrático.

O cerne do desafio visto por estes que entendem a necessidade da cooperativa é vencer a fragilidade da cultura autogestionária, associativa e cooperativa que marca as atividades fragmentadas dos trabalhadores, fruto do mundo das necessidades materiais, sociais e afetivas que os atingem. Precisam, portanto, de liberdade substantiva para imaginar, querer e lutar por uma vida cooperada.

Consideramos que a concretização dos direitos humanos está diretamente ligada à ideia de sustentabilidade e esta já encontra-se nos princípios constitucionais que o apontam como valor fundamental, voltado a determinar direta e imediatamente a responsabilidade do Estado e da sociedade pela realizaçáo do desenvolvimento como acesso ao direito ao bem-estar de todos os indivíduos.

Constitui-se, por isso, em um movimento social que agrega as racionalidades justas, estando além de simples concepçóes de Estado, sociedade civil, tecnologia, Direito, Pedagogia, organização do trabalho e relaçóes sociais. Não se trata apenas de criar riquezas a partir dos pobres para os pobres, ou de não sermos mais o "irmão pobre da grande economia". Trata-se, também, de criar, a partir de atividades coletivas e solidárias, trabalho e renda para quem deseja e, principalmente, para os indivíduos munidos de diferentes vulnerabilidades. $\mathrm{O}$ trabalho e a renda geram motivaçóes racionais para a inclusão de indivíduos na evolução civilizacional e agregam esforços para lutar pela emancipação social. Além disso, fortalecem os aspectos educativos formais e informais e criam culturas de respeito mútuo pela dignidade da vida, princípio fundamental dos direitos humanos e do deenvolvimento social.

\section{REFERÊNCIAS}

BAUMAN, Zygmunt. A sociedade individualizada: vidas contadas e histórias de vida. Rio de Janeiro: Zahar, 2008.

DUVIGNAUD, Jean. A solidariedade - laços de sangue, laços de razão. Lisboa: Instituto Piaget, 1986. 
FRANTZ, Walter. Empreendimentos solidários como espaço de educação. In: Cadernos Unijui, Ijuí: Ed. Unijuí, 2006. (Série Economia Solidária, 3).

- Organizaçôes solidárias e cooperativas: espaços de educação e a bases da Economia Solidária. Ijuí, RS: Ed. Unijuí, 2008.

HABERMAS, Jürgen. A inclusão do outro - estudos de teoria política. São Paulo: Loyola, 2002.

. Teoría de la acción comunicativa - racionalidad de la acción y racionalización social. Madrid: Taurus, 2000. V. 1.

. Três Modelos Normativos de Democracia. São Paulo, Revista Lua Nova, n. 36. 1995.

MANCE, Euclides André. A revolução das redes: a colaboração solidária como uma alternativa pós-capitalista à globalização atual. Petrópolis, RJ: Vozes, 2008.

MORIN, Edgar. O método 5 - a humanidade da humanidade. Porto Alegre: Sulina, 2008. MORIN, Edgar. O Método VI - Ética. Porto Alegre: Sulina, 2005.

SEN, Amartya. Desenvolvimento como liberdade. São Paulo: Companhia das Letras, 2000.

SILVA, Enio Waldir da. Extensão universitária hoje: processo dialógico da ação integradora e emancipadora. In: BARCELOS, Eronita Silva; RASIA, Pedro Carlos. Economia Solidária: sistematizando experiências. Ijuí, RS: Ed. Unijuí, 2010.

SILVA, Enio Waldir. Projeto de extensão tecnológica. Economia solidária e cooperativismo na região de Ijuí. Ijuí: Ed. Unijuí, 2013.

SOUSA SANTOS, Boaventura de (Org). A Globalização e as Ciências Sociais. São Paulo: Cortez, 2002.

SOUSA SANTOS, Boaventura de. Por uma concepção multicultural de direitos humanos. In: Sociologia jurídica crítica. Madrid: Trota; Bogotá: Ilsa, 2009.

SOUSA SANTOS, Boaventura de (Org.). Produzir para viver: os caminhos da produção não-capitalista. Rio de Janeiro: Civilização Brasileira, 2000. p. 23-77.

TOURAINE, Alan. Podemos viver juntos? Iguais e diferentes. Petrópolis, RJ: Vozes, 1998. ZOLL, I. O que é solidariedade hoje. Ijuí, RS: Ed. Unijuí, 2007. 